\title{
Factors Influence on Personal Practical Artwork
}

\author{
Hamdzun Haron \\ Centre for General Studies, Universiti Kebangsaan Malaysia, 43600 Bangi, Selangor, Malaysia \\ Email:hh@ukm.edu.my \\ Nor Afian Yusof \\ Centre for General Studies, Universiti Kebangsaan Malaysia, 43600 Bangi, Selangor, Malaysia \\ Email: affian@ukm.edu.my \\ Narimah Abd. Mutalib \\ Bukit Changgang Primary School, 42700 Banting, Selangor, Malaysia \\ Email: neryzone@yahoo.com
}

Doi:10.5901/mjss.2014.v5n27p1482

\section{Abstract}

The problem of this research is to analyse the artist's working process in a certain period of time. The aim of this study is to distinguish the intrinsic and extrinsic factors that influenced the artist during the whole working process. This research was carried out by using the case study method. Following the aim of this faculty, the researcher had analysed the working process carried out based on his diary and photographs taken from the beginning until the end of the working process. Information gathered by the artist had shown that the processes of producing sculpture were influenced by two main factors. Firstly, the Practical Consideration of artwork, which included the process, went through by the artist, such as the Working Environment and Preparation of Material, Tools, and Processes. Secondly, the Imagery, Idea and Processes Involved with the Artwork were such as Way of Working, and Sources and Influences Associated with the Imagery in the Sculpture.

Keywords: personal practical artwork, intrinsic and extrinsic, sculpture, artist, working Process

\section{Introduction}

The following research was carried out to observe the creativity that the artist had gone through. The artist is a sculptor. He had chosen clay as a media to form his artworks. According to him, various factors had influenced him upon creating his artworks. Some of the factors are practical consideration of construction, emotional and conscious and unconscious source of imagery.

The forming process of the sculptures was done at the ceramics' workshop, Faculty of Art and Design, Mara Institute of Technology (UiTM), Shah Alam. The artist had managed to produce 11 pieces of ceramic sculpture of different creative and unique forms. The whole process took four months to be completed.

\section{Description of the Artist Artworks}

Hamdzun Haron, 47, is from Tumpat, Kelantan, situated in the East Coast of Malaysia. Kelantan is long famed for its artistic culture and heritage. Malaysia's most potent Malay art forms like giant kites, one-and-a-half kilo spinning tops, silverware, batik, songket and woven products all have genesis in Kelantan.

The artist grew up at a very early stage. He was exposed to the intricacies of keris (dagger) making. His father was a 'pandai keris' or a wordsmith who specialised in producing the traditional dagger adorned by Malay warriors. The artist's constant exposure to smelting metals at the furnace, understanding the different degrees of flame and working with heat and hammer to beat the keris into shape were lessons he put to good use. His understanding of the difficult technique in carving complex patterns on the hilt of the keris, which requires strong yet gentle hands, has enabled him to apply this family trade to his creation.

Sculpture, to the artist is a mode of conveying things that are extremely difficult to express verbally. As much as 
music can express abstract ideas, poetry can take familiar words and breathe new life and meanings into them, sculpture gives opportunity to communicate ideas that do not fit into any languages. Many of man's noblest works of art have been produced in the three-dimensional forms that distinguish the characteristic of sculptural works. Sculpture's significant function has been to express man's changing ideas of divine or spiritual power.

The unlimited choice of subjects is clear in the sculpture. An artwork could not really appear interesting without experience, education and high disciplinary attitude of its inventor. Though, sculptors are free in forming their work, they should still go through those complex and scientific processes such as the blending of materials and the management or the control of firing temperature.

The artist believes that an artist should be a master of his craft. Otherwise, he will never be aware of his own vision. There seems to be a popular notion today that anyone can be an artist, anything can be art, whatever a human being creates is somehow good if only the person's intentions are good. This, to the ratios is only half of the equation. It takes the spirit and inspiration of creation as well as dedication and hard work in order to be a successful artist. All artists he admires have mastered their media at least to the extent that appropriates to their ideas. However, the artist does feel that craft for craft sake is as disappointing as a good idea poorly executed. Putting a sculpture together in a masterful way, lavishly and painstaking attention to detail is useless if the concept behind the work is questionable. Similarly, too high a finish quality on any work can be just as bad as poor craftsmanship. The artist has tried to create and organise a work that will last a long time, but that does not seem to beautify it. The detail should hold up to scrutiny and support the sculpture without calling attention to them.

This also reflects his feeling on how a sculpture should be. A sculpture must have its own entity, and soul, in a way. It should have a distinct personality. To me, the most meaningful and memorable works are those which make a personal connection, that make him feel that he had got to know the artist in some ways. Even if the person who makes the object lived two thousand years before he was born, that person's work could still exude a living presence, and strong personal and emotional feeling. In the end, a work should leave the impression as one has just met someone who is not likely to be forgotten.

Previously, his artworks were created for functional and commercial purpose. All the work also was glazed. Moving from practical and commercial art, the artist's artistic intrinsic rewarded him with works of high esthetic value. In his latest work (Guest Series), it portrays the blending of emotion, philosophy, and spirituality. (See appendix I). His works are classified as 'free standing sculpture'. Made of local clay (sayong) for its hardwearing properties. Guest Series has the detail of Arabic Lettering. Dressed in green as a major colour but evolving in darker tones, its texture is grainy in appearance. Arabic calligraphy (jawi script) either Kufic or Naskhi have long since medieval periods been a main source of decoration for Arabic artist. The artist had taken this to bring his designs a harmonic and aesthetic feel.

The artist created works that carry an identity of his own with a unique self-expression that reflects his ability. This identity lies in the exquisite design of his ceramics handles. He treated the handle in his sculpture as a sculptural piece. Through experimentation, he used the 'pulling' technique, a risky process, especially during firing, joining and colouring. The artist has mastered this process.

The theme of this sculpture is based on social issues. It tries to reveal the issues of Malaysian's social life, especially the Malay society who are highly respectable for their courtesy and manners, which from time to time has faded away. This is due to the family ties and education that have been neglected. Outside influences too have circulated the Malay society. One of the aspects of everyday life that interests the artist in his sculpture was on how the Malays attend to their guests.

The Malays always show respect to all guests who visit them. Each guest would be served with delicacies and drinks. Good manners, soft and gentle languages use in speech are practiced by the Malays in entertaining their guests. To this, the artist had made use of images of teapot as a symbol to how the Malays attend to their guests in order to convey the messages in his sculpture. The sculptures entitled 'Simpuh', 'Sila, 'Sapa', 'Jemput', "Salam', "Sembah" and 'Kelubung' portray the artistic manners that could bring awareness to the Malays, especially the youngsters who have been neglecting the practice of decencies in entertaining their guests.

"Simpuh" (Kneel) and "Sila" (Sited in cross-legged): In the Malay society, kneeling down and sitting in cross-legged are how the Malays sit on the floor that has been normally spread out with mat (tikar). There is a difference between kneeling down and sitting cross-legged. The former refers to women (See figure 5), whereas the latter refers to men, respectively. This is one important and decent way to reflect the respect towards guest.

"Sapa" (To Greet): Ways of communication (languages) and friendliness are vital during guest entertainment. In a way, guests are attended warmly and sincerely. Each member in the family should greet the guests, and normally greetings used are 'Apa khabar?' (How are you?), 'Bila sampai?' (When did you arrive?) and so forth. Any members of the family who does not greet would be considered arrogant. 
"Jemput" (Welcome): Guests are normally served with drinks or foods. According to the Malay custom, guests would drink or eat after being invited by the house owner and words used as greetings would be 'Jemput makan atau minum' or 'Please help yourself'.

"Salam" (Handshake): Handshake is an action between two persons such as a host and his guest when they first meet. Handshake is also practiced when the guest is to excuse himself or to take leave. As for children and youngsters, they would kiss the hand of their elders during handshake to show respect.

"Sembah" (Homage): In the Malay society, practices in the palace are normally are still in use. One of them is the way of approaching the king (Sultan). Each guest should pay homage to show his or her respect.

"Kelubung" (Veil): According to Islamic teaching and perspective, it is necessary for all women to cover their head in veil upon meeting men. During the old days, women who did not cover their head were considered not respectable. Nowadays, veil or kelubung is only a practice outside the home, but not upon meeting guests at home.

\section{Practical Consideration of Artwork}

\subsection{The Working Environment}

The artist believed that a workshop was the most comfortable and best place to work at. The preparation for a complete ceramic workshop usually needs a high cost. Therefore, in order to complete his work, the artist had been making use of the Ceramics Department's workshop at the Mara Institute of Technology, Shah Alam. At the workshop, the artist had to share with the students of the department. The workshop was occupied with students. However, it did not affect him since he was used to the environment and had a four years of experience during his diploma course. "I like the environment of the workshop as I could exchange and explore my ideas with the students and lecturers there". (17.11.12).

The workshop was hot since the students carried out firings. Students would start the firing only when the pots were completely dried. Firings were normally carried out in two and three kilns at one time. "I felt uncomfortable to get on to work on sculpture... Just prepared the clay on the whole day". (25.9.11). The artist felt that the climate could somehow affect his mood of creating his artworks. He felt that mood was important and along with his experiences as a sculptor, a moody condition could ruin the fluency of creating ideas for his art pieces. Other than that, high temperature could cause cracks on the joints. "I always cover the sculpture with plastic to avoid drying too fast". (15.10.12).

The artist, to solve the above problem had carried out an excellent plan "Started to throw multiple-section form of sculptures in big and tall scales...". (13.10.12). The workshop was more comfortable and I felt easy to work since many of the student had finished with the firing works and that the weather was cold. The artist had started to form his sculptures somewhere in mid October, during the early rainy season. The sketches were prepared earlier in mid September. The rainy season could at least lessen the hot climate.

The workshop was spacious. Producing a large form of a multiple-section sculpture needs a large space. Spacious area did not only simplify the artist's effort on forming sculpture. The artist too could move freely upon observing his sculptures from different corners so that the sections joined were balance and there could be a continuous flow on the handles. "Used 3 tables in the middle of the workshop for the formation process". (21.10.12).

"Space and light are vital in producing ceramic arts. A spacious workshop is needed to create comfort to the artist during his working process. The artist could also observe completely his artworks and feeling more pleasant to work in natural light than artificial lighting". (Peter Cosentino, 1987, p. 44). Based on the above notification, the artist himself felt that bright surroundings in the workshop were important so that forms and colours wanted could appear in a satisfied manner and the artist would not be bored to continue with his art pieces. "The workshop is always brightened by the florescent light and the white walls that surrounds it help me in observing the sculptures formed". (14.10.12).

\subsection{Preparation of Materials, Tools and Processes}

In the early stage, the artist faced a dilemma whether to use local or imported clays. "Made up his decision to use local clays from 'Sayong'... easily formed and suitable for huge forms". (12.9.12). 'Sayong' clay is normally used to form traditional pots, which are better know as 'Labu Sayong'. 'Sayong' clay is low in price, easy to obtain, has strong body, if fired in high temperature. One of its special features is that it does not have to be mixed with 'grog' (fired clay crushed to fine particles). The body can afford to stand strongly, and be supportive, during the formation process of tall sculptures.

Apart from clays, ceramics artwork also needs other tools or equipment for its practical works. The ceramics workshop chosen had brought many advantages to the artist, especially in terms of equipment such as potter's wheel. "Used potter's wheel to build sculpture s in big scale". (13.10.12). The fully equipped workshop with about twenty potters' 
wheel is sufficient for the artist to carry out his work by using the throwing technique unlimitedly. This could definitely quicken the process of forming sculptures that need to be assembled (multiple-section form). The artist did not have to move the thrown form immediately to throw another since many wheels were provided and available especially during the semester break or when the students are on vacation.

Other than the potters' wheel, the artist had preferred to use the personal and ready-made tools. These hand tools were used during which the clays were in a leather hard stage. "Saw blades were used to form lines on the sculptures". (1.11.12). Some of the materials and tools found at home (e.g. comb, fork, and others) too had been useful for the artist in order to produce different textures. "Impasto technique...used fingers to smear the clays...formed actual texture". (16.10.12). The artist realised that using his fingers could possibly add to a more personal, sensitive and expressive quality to the form.

The artist had chosen suitable time, that was when the students were on vacation. This also enabled him to use two electrical kilns measuring three $1 / 2$ feet high without any obstacles. "The first sculpture was fired at $8.00 a m$ to 3.00pm... firing was done to stiffen the body of the sculpture". (20.11.12)

In this project, the artist had been making use of the glazing technique. He had been using oil paint (Rowney Georgian) and modeling colour (Mr. Color Spray). These colours were also used in his previous artwork, the effect was incredible and could attract viewers' attention. "With the use of brushes and palette knife, oil paint formed strokes on the surface of the sculptures... produced the blending of cold and warm colours". (7.2.13). The oil paint was similar to the technique of painting on canvas. Effects produced by oil paint are different from glazes. The artist felt a great sense of satisfaction upon using oil paints for they could produce various colours, exactly as required by him.

"I have chosen the calligraphy black marker pen to make patterns on the surfaces of the sculptures easily". (13.2.13). The letters could be written neatly and clearly, for the marker pen is suitable for calligraphic purpose.

The processes of cutting and welding of steel to form the three-legged stand were done at the Industrial Design workshop (IDE), UiTM. "Prepared a three-legged stand for all sculpture". (15.12.12). All sculptures produced by the artist needed support to stand up straight. To this, the artist used steels with the diameter of $1 / 2$ centimetres to form the threelegged stands as supports to the sculptures. "I purposely chose steels with small diameters and painted them in black so that the sculptures would appear dominant". (19.12.12)

\section{Imagery, Idea and Processes Involved In the Artwork}

\subsection{Ways of working}

\subsubsection{The Creative Process}

According to the artist, remembering of how the idea of this sculpture was obtained was a big deal. The time given to complete this piece was too short. He had the idea through his different emotional experiences during his kampung life and by mixing around with the modern society nowadays. His expressions were based on the Malay society that is very well known for their culture, value, attitude, and their warm welcome to their guests.

Based on the above idea, the artist tried to fit the image to be used in this artwork. He decided on the use of a teapot. This is because, teapot is one of the drinking items often used by the Malays to welcome their guests. Beside this, the artist had blended various images and designs such as 'keris' (dagger) and jawi script in order to obtain a satisfied piece. "Teapot, dagger and calligraphy were chosen as images for this sculpture....as a symbol of Malay culture and society". (10.9.12).

Based on his experience, looking at reference books was the first step made to create a design he desired. "... Natural motif was used, the main idea for the formation was a pitcher plant". (3.9.12). The artist had chosen the image of a pitcher plant for its unique, soft and attractive form as an introduction to the new generation on wild plants that could hardly be seen by them. This experience is mentioned by Peter Cosentino (1987, p. 16), " The natural world provides an inexhaustible supply of visual images; its shapes, textures, patterns and colours all translate beautifully into ceramic terms". Other than this, to fit the theme used, "teapots, keris (dagger) and calligraphy were chosen as images for the sculptures...". (10.9.12).

After setting the images to be used for his sculpture, sketches were drawn on papers. The artist has his own style of producing the sketched sculpture to be formed. The ideas of the basic sculpture form were sketched in a form of twodimensional. The artist believed that two-dimensional sketches could help him to speed up his ideas (fast sketches). These sketches could be done fast and within five minutes, at least eight ideas could be obtained through this. "Seventeen ideas were completed...The sketches had obviously helped me in producing different and unique forms". 
(8.9.12). The sketches of the final form were important since they acted as guidance in the formation process of the models and sculptures. In Glenn C. Nelson (1883, p. 153), Don Reitz suggested "Make a sketch of the final form, deciding upon the number of pieces, how they will be thrown, and how they will be joined".

The artist had formed two sculpture models following measurement as one of the experiments before the actual sculptures were built. The models were considered as a trial and error because some of the actual models formed earlier ware altered. This was unavoidable. Various sub-conscious and unconscious ideas came spontaneously when the artist had the sculpture in front of him. "I decided to build the model measuring 1 feet high in the first place so that the threedimensional view would be clearer". (17.9.12).

The artist was concerned about the basic element and the principle of design on his sculpture. This could definitely help him in producing an artistic form and design. To achieve this too, the artist had emotionally observed his artwork. This kind of emotional feeling had somehow helped the artist to communicate with his sculpture. Through this, the artist could realise the weaknesses and the extraordinariness of his sculptures. The principle and the element of design used are form, texture, shape, balance, harmony, and movement.

Form: The artist had combined the geometric and organic forms in all his sculptures in order to get the harmonious form. The artist believed that the geometric form from the throwing technique had produced a form, which are stiff, stable, and perfection. Herberholz (1994, p. 53) stated that "geometric form often seem less emotional than free form and give the viewer the feeling of perfection". Meanwhile, the organic form built spontaneously from the pulling handle appeared to be soft. "The pulling handle could create tenderness to the form of the sculptures". (21.10.12).

Texture: According to the artist, the smearing of clay with the used of thumb could produce a rough (actual) textured surface on the artist sculpture. This is effective as what was done by Van Gogh in his paintings. "Textures created by Van Gogh had trapped light that created lucidity to his paintings whenever observed." (Ragans, 1997, p. 201). "The surface of the sculpture was scratched... brushed with slip, then, smeared with clays". (16.10.12). The artist also had taken into account the visual texture of calligraphy that covered $90 \%$ of the form. "Jawi scripts were used repeatedly to produce the patterns". (18.2.12). (See Appendix I (A)). Both of these texture therefore only function to vary the designs on the sculpture and to draw people's attention to the various areas that had been emphasised.

Colour: "... Preserving the tenderness of natural color". (7.2.13). The artist tried to maintain the colour of nature on his sculpture. There were the existence of cold and warm colours, in harmony, such as black, orange, red, and green. The use of these colours did not obstruct the viewers' eyes. The artist suggested that if his sculptures were to be coloured with various colours, they would be more complicated and would not turn out uniquely.

Balance: To build a huge multi-sectioned form of sculpture, forms are needed to be arranged in balance. Balance is important for the artist's kind of sculpture so as to avoid defects (off balance or collapse). He had applied two kind of balance in his sculpture: symmetrical and asymmetrical balance. The symmetrical balance sculptures look stronger, proper and more controlled. "Both sides of the sculpture was attached by the same spouts, not only by the size, but the form". (17.12.12). (See appendix I (D)). These sculptures are planned carefully following certain measurement. It had its centre of attraction and could produce the effect of harmonious.

Meanwhile, the asymmetrical sculpture looks free and spontaneous. "Spout on the left side was larger than the right". (8.9.12). Overall, the forms were planned following the informal arrangement and size in order to avoid boredom. The artist preferred to produce asymmetrical balance sculpture, as it needed concentration and ideas to be more interesting. (See appendix I (G)).

Line: "Coiling of handles were arranged until fibrous lines were formed...created different situations to avoid boredom". (15.10.12) The coiled handles had somehow showed fibrous lines on the sculptures. (See appendix I (F)). These lines could proportionate or make the stiff sculpture balance to one part (handle) that appeared fibrous, but still portrayed tenderness and flow.

Subconscious aspects of the work: The artist during the forming process obtained subconscious aspect. The subconscious aspect would be seen at the handles formed in spring with the pulling technique. The joints produced handle with different direction. "Handles at the leather hard stage were assembled....Appeared such as twisted strings" "The handles met to an end accidentally...". (17.10.12). The tail on the plate that acts as the base for the sculpture accidentally becomes the end of the handles. This part plays an important role in showing how the artist had succeeded in unifying the two contrasting forms of teapot and plate.

The inner part of the thrown spout consists of stripes (lines). His seven years of experience in forming throwing technique sculptures had caused the accidental effect of stripes and textured surface. The stripes were also produced from the artist's thumb during the formation of the thrown spout. "I preferred the use of lines by finger tips on the surface of thrown spout". (13.10.12)

The technique of spraying colour to the body and handles of the sculpture had created forms. This is resulted from 
the spraying of colour especially to the hidden parts. "Spraying of model roughly.... Could produce light and dark parts". (7.2.13). This enabled the artist to produce a brighter tone of calligraphy in order to attract viewers. "The bright parts to the darker areas were covered with calligraphy...the calligraphy written become slowly lost in sight". (18.2.13)

\subsubsection{Method of Working}

To view the working methods, the artist had chosen the sculpture entitled Siri Tamu (Guest Series) XI - Sila (Sit crosslegged) (See appendix I (E)) as a guide and represents the other forms. This is due to the similarities occurring in all the forming process of the sculptures. Clay preparation was the first stage the artist went through to form his ceramic sculpture. As mentioned earlier, the artist used 'sayong' clay because of its low price, easily obtained and its high quality. The clays bought had been processed and the first stage was wedging. The correct technique of wedging is important to ensure that air bubbles would not appear in the clays, to align coarse particles and to develop a homogeneous consistency. "I preferred using the spiral technique of wedging...". (17.9.12). (See figure 17a). The artist wedged the clays to his satisfaction until no air bubbles could be found. The air bubbles could probably cause centering problem during the throwing session and damage to the sculptures during the firing stage.

The artist used the modelling (constructing) technique to form his sculptures. This form was used as guidance in creating the rest of the sculptures by assembling different forms and shapes. To build up different forms, the artist had used the throwing technique. "The throwing technique, with the use of potters' wheel was the main choice for different shapes could be formed easily, within a short period". (13.10.12). (See figure 17b). This technique was chosen since many forms could be created within short periods and that the artist had been so comfortable and skilful with this technique. Other than that, this technique was suitable for the sculptures of multiple section form.

The technique of throwing multiple section form, to the artist, was suitable to form tall sculptures. Don Reitz said "Many potters find it more convenient to throw an extremely tall or large shape in section. Moreover, to throw a very huge form in a shot is quite a problem. The sections should be allowed to dry to a leather-hard state and then joined". (Glenn C. Nelson, 1983: 152). Based on the sketches made, different forms were thrown separately and joined together during their leather hard stage. "Based on the sketches...the parts to be joined were scratched and applied with slip that functioned as glue". (14.10.12). (See figure 17c, d, and e). Following this, the sketches for the final form were important to ensure the total sections to be thrown and how they should be joined. After all sections were joined, the artist created textures by using his fingers. (See figure 17f). Impasto technique was used to create these textures. Clays were used to be spread out on the surface of the sculptures, during the leather hard stage. This was to ensure that the textures produced would stick well to the body. These textures could produce contrasting surface such as smooth and rough and could avoid boredom to viewers. "Use thumb to press the soft clay onto the sculpture spontaneously to obtain the texture". (16.10.12).

The artist, to decorate his sculptures used decorative handles by the pulling technique. (See figure $17 \mathrm{~g}$ ) This technique was used in order to form rounded handles with sharp pointed ends. There were two forms of handles made. The first was straight and the second was the uncontrolled and spontaneous coils. (See figure 17h). "The pulled clay then is dropped onto the floor to form an original coils". (14.10.12). After the handles were prepared, they were left for the whole day before they were joined and arranged on the bodies. The handles were arranged in proper order to produce flowing movements that relate to one another. (See figure $17 i$ and $j$ )

"...Threw plate form that suited the sculpture's size...to appear balance". (13.10.12). (See figure 17k) The plate was left open for a day to reach a leather hard stage. This is important to ensure that the plate would be strong enough for the turning and trimming process. The process of producing textures was carried out carefully so that the surface of the plate would not wreck during the process of smearing clays with fingertips. (See figure 17l). Finally, tails were pulled and it was joined on the bottom part of the plates. (See figure $17 m$ and $n$ ).

A systematic drying process was needed for the multiple section form of sculptures created by the artist. After the sculptures were completed, they were covered with plastics for four days so that every section joined would be dried up slowly and accordingly. According to Don Reitz "Cover the assembled form with plastic for three or four days. This will equalize the shrinkage of the different parts and prevent cracking". (Glenn C. Nelson, 1983:153). The sculptures were left to be dried naturally at room temperature during the fifth day. (See figure 170). A sculpture normally dries up according to its thickness and the weather. It is important that a sculpture should be completely dry to avoid cracking or breaking during the firing stage. Cracking could not be detected easily after the drying stage. "Sculptures were left to dry for two weeks...the body of the sculptures turned white and dusty when touched, showing that the sculptures were completely dry". (20.11.12)

The artist used electric kiln for the bisque firing. (See figure 17p). The operation needed a short period and was 
easily carried out, after being computerised by the technician of the Ceramics Department. According to Peter Cosentino (1987: 44), "Using electric kilns has many advantages. Some of the advantages are self-contained, fired cleanly, and take up less space". Based on the statement, the artist was completely true in making the decision to use electric kiln even though gas kilns are available at the workshop. The artist only used the bisque firing technique for his sculptures did need not to be glazed. The temperature increased slowly so that the content of water in the body did not dry up drastically in order to avoid damage to the sculptures. A high temperature of 1000-degree Celsius was needed so that the bodies of the sculptures would be completely fired and that the water particles would be completely dried. This was important to produce a strong body. Other than this, the emulsion paint to be used as undercoat could absorb into the bodies during the colouring process. "Carefully, sculptures were arranged in the kiln for the first bisque firing. Not too close so that the heat would flow regularly". (20.11.12). For the tailed plate forms, the artist had prepared tall cylinder props made of clays for their bases.

In the colouring process, oil paint, and colour model from the Spray Can were used. The colouring process on the surface of the sculptures was similar to the process of painting on canvas. "The surface of the sculptures were painted with emulsion for undercoat". (2.2.13). (See figure 17q). The purpose of emulsion paint was to act as an undercoat and to avoid the colours of oil paint to absorb into the bodies, resulting in pale colours. Emulsion paint was easily dried up.

"Waited for sometime for the emulsion to dry up... The colouring process was started by using oil paint as the base". (6.2.12). To produce the blending of warm and cold colours on the surface of the sculptures, the artist used brush. It was used since the combination of colours desired could be obtained easily. Warm and cold colours were chosen by the artist to portray the colours of nature. Layers of oil paints were coated to produce harmony. (See figure 28r, s, and t). After confirming the suitable colours to the forms, the artist then refined them with the coloured model (Mr.Color Spray). "Colours were sprayed roughly...formed bright and dark tones". (7.2.12). (See figure 17u). As it was expensive, the artist did not colour the whole body with colour model. As an alternative, the artist used oil paint as the base colour and colour model for the finishing.

"Everyday, the sculpture is touched to ensure that it is dried completely". (13.2.12). The colours were dried up at room temperature for five days. The artist had purposely took a long period to let the colours to dry completely. This was to ensure that there would not be any fingerprints on the sculptures and to simplify the process of writing calligraphy on them. (See figure 17v). The calligraphy technique was the second stage of decorating the surface of the sculptures. "Chose "Naskh script' for the sculpture". (17.2.12). This form was chosen, as it was easy to write. Permanent marker pens (chisel and bullet-eye) ware used. Different sizes of marker pen and letterforms were used to produce the elements of space and visual textures on the sculptures. (See figure 17w)

\subsubsection{Emotional Aspects of Working Process}

The artist felt that the emotional aspect occurred during the formation process of his sculpture. "I could feel like having a conversation with it (sculpture)...I could feel the weakness point of the sculpture". (15.10.12). "I like what I had done especially when I used the clays to smear, produce textures and to join the handles...". (16.10.12). This is probably because the artist was paying attention to his sculptures. His daytime was mostly spent on his sculptures.

Green is the artist's favourite colour. He feels that this colour could create a feeling of calmness. It also reminds him of the green forest that could bring together peace, mind, and soul whenever one is in that surrounding. To this, the artist had tried to create an artwork that represents the natural surroundings full of beauties, purity and gentleness. These suit his concept of wanting to portray the life of the Malay society. "Colour modelling in green, orange, red and black were sprayed on the sculpture...creating harmony in green". (2.2.13)

Personally, besides these, the artist also like the shape of the teapots produced with the throwing technique. His interest on teapots was obviously seen in his Diploma Show in the year 1991. The artist, at that time had succeeded in exhibiting various shapes of teapot with the throwing and casting techniques. "Looking through the pictures during the Diploma Show- 1991 as an additional references...various sets of teapot were exhibited". (6.9.12) 


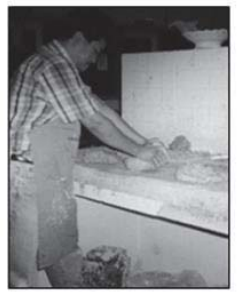

(Fig. 17a) Wedging the Clay

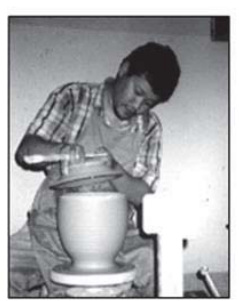

(Fig. 17c) (Constructing) the
Form (I)

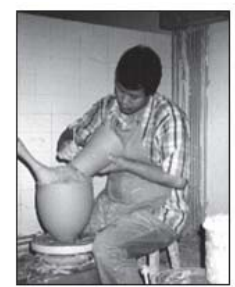

(Fig.17e) (Constructing) the

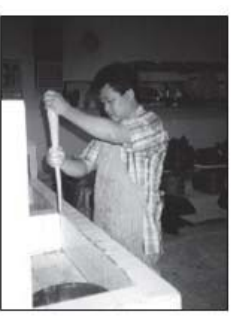

(Fig. 17g) Pulling the

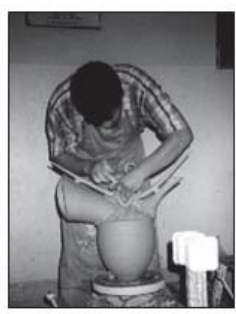

(Fig. 17i) Assembling coils

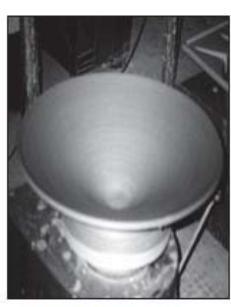

(Fig. 17k) Thrown plates

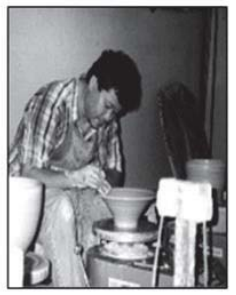

(Fig. 17b) Throwing the Form

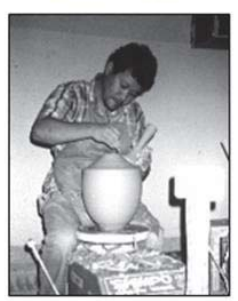
(Fig. 17d) (Constructing) the
Form (II)

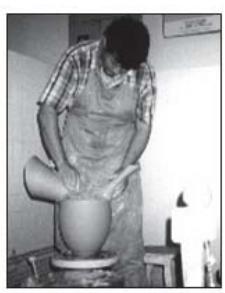

(Fig.17f) Applying the

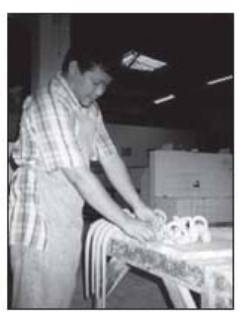

(Fig. 17h) Forming coils

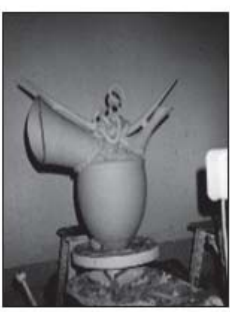

(Fig. 17j) Finished form of sculpture

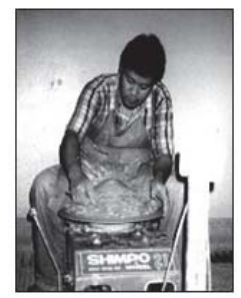

(Fig. 171) Formed texture at 

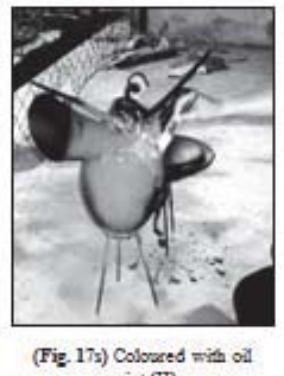
paint (II)

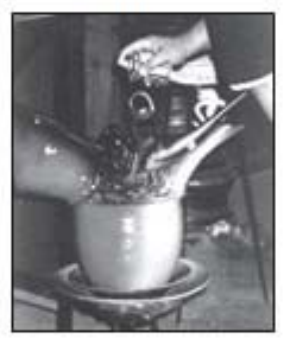

(Fig. 17n) Refioed with colose spray

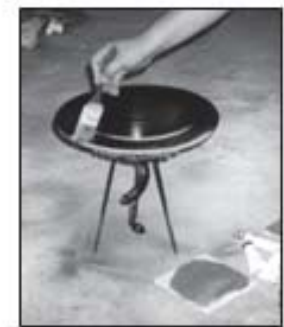

(Fig. 17t) Colocxed with oil paint (III)

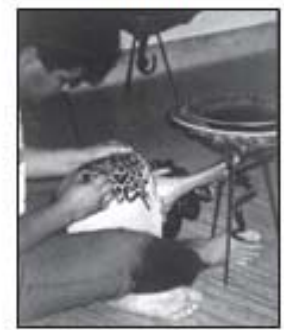

(Fig. 17v) Writing the calligraphy (Jani seript)

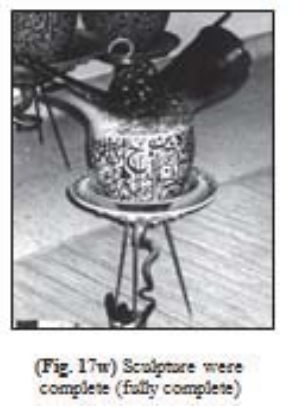

\section{Sources and Influences Associated with the Imagery in the Sculpture}

\subsection{Unconscious and Conscious Sources of Imagery}

The artist had purposely blended several different images in his sculptures to create a unique form, with his own identity. Part of the images used was a creative teapot that had been the main form in every piece of his created works. Whereas, the image of dagger (keris) and calligraphy had been combined as additional image to be fitted to the theme to be conveyed. These images were produced from the artist's personal experience. The artist suggested that the blending of different images is an original idea by him and was not influenced by any other existing sculptures. According to him, any similarities that found to works by some other artists were an accidental. However, the artist found that unconscious sources of imagery might have had an influencing factor in spite of his determination to be original.

Unconscious image where there is similarity to the form of sculpture created by the artist is the teapot by Belinda Paton, entitled Tornado Teapot. (See figure 18). "...The handle formed by spontaneous pulling technique and the use of the three -legged stand was similar to the sculpture of Guest Series". (29.12.12)

Another work Belinda Gabryl had created is entitled Tornado Teapot. It reflected the same form to the artist's works. "I happened to look at work by Belinda Gabryl...Teapot with tailed plate as its base and a three legged stand to support it... There are similarities to my sculpture". (13.3.13). (See figure 19).

"Wing-handled vase, and four-legged pot were ornamented with calligraphy ... whereas Guest Series was adorned with Naskh script". (18.2.12). (See figure 20). This is a vase from Malaga. The similarity with the artist's artwork was seen on the surface decoration of the pots that were covered with different sizes of calligraphy. 


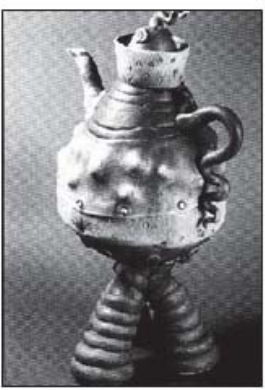

(Fig. 18) Belinda PatonTernado Teapot, 1997

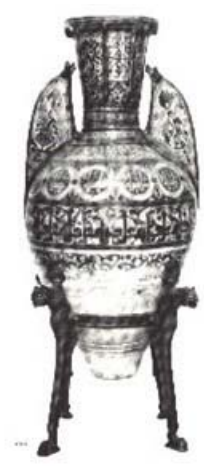

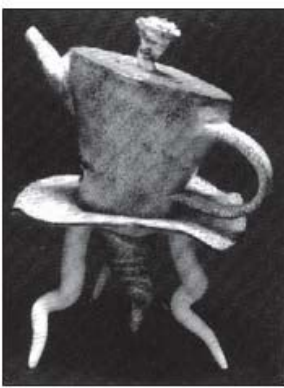

(Fig. 19) Belinda GabrylTornado Teapot, 1988

(Fig. 20) Wing-handled

vase. The surface of the

vase was decorated
with different quality

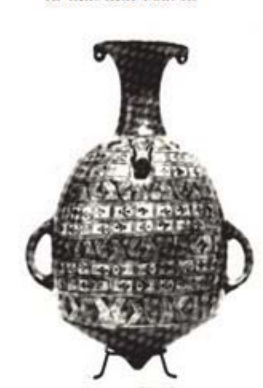

(Fig. 21) Water jars

with tripod as a stand.

Classic Period

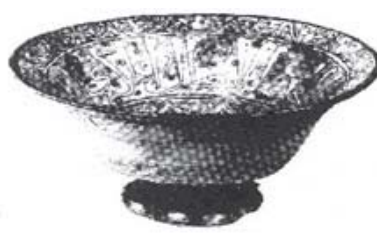

22) Bowl of brown and yellow s grafito Cairo. $14^{\text {th century }}$

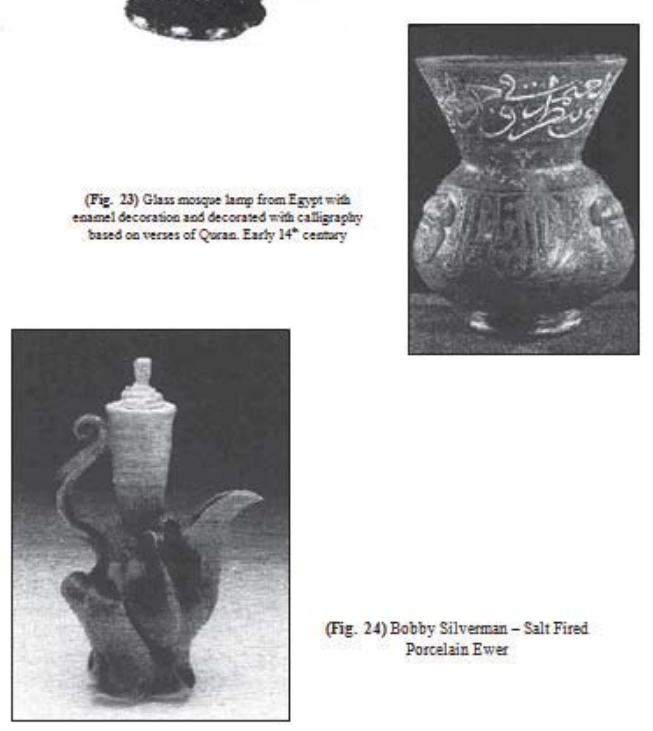


Other than these, a pot from Peru that functions as a water jar is obviously similar to the artist's sculpture that is the bottom part or the footing. (See figure 21). "The pointed foot of the jar, which does not permit the jar to stand on its own... a three-legged stand was created to support it". (2.1.13).

The artist's sculpture was consciously influenced by the Islamic art of the 14th century, from Egypt. "I have always admired art pieces such as bowls and glass lamps that are normally used to decorate mosques, with beautiful calligraphy...they have been an inspiration to me". (3.9.12). (See figure 22 and 23). According to David Talbot Rice (1996, p.133), "arts from Near East had shown a newly formed identity in the forms and styles".

"I have admired works by Bobby Silverman, entitled Salt fired porcelain ewer...succeeded in creating a unique form of teapot sculpture, based on nature, especially on the handles". (12.9.12). (See figure 24). The artist found that the naturalistic theme used by Bobby Silverman had attracted him upon using it to produce a sculpture with tender and pleasant characteristic.

\subsection{Symbolism}

According to an art historian, in his communication theory, he mentioned that an art piece is note of real experiences (Mulyadi Mahmood, 1993, p. 6). As for the artist, the theme of his sculpture 'Siri Tamu' is based on his past experience. The artist was brought up in the Malay society that is full of decency and rich for its cultural value. These have obviously created a self-discipline attitude of the Malays in every day life. "From the references made, I was attracted to one of the aspects of life practised by the Malay society...that is on how the Malays entertain their guests...and now, the culture is less made a practice". (25.9.12).

The Malays normally show respect to their guests. Every guest would be served with drinks and food. The Malays are concerned of their attitude and conversation in attending to their guests. The usual terms they used to show their welcome is 'Jemput makan' (Help yourself with the drinks and foods). Therefore, to convey the message consisted in his sculpture, the artist had made use of teapot as a symbol to the Malay society that practices decencies in attending to guests. The titles of the sculptures too had somehow brought into conscious that the Malay society nowadays seemed to be casting aside the practice of decencies.

As a symbol to the Malay society and culture, the artist had written the calligraphy (Jawi script) on the sculpture's surface. According to the research made by Associate Professor Siti Zainon Ismail (1985, p.188), "the Malays had used calligraphy since the 14th century, with the arrival of the Arab traders to South East Asia. Calligraphy was used in writing, on tombstones, weaving in the form of 'songket', in embroideries, in carvings to decorate doors and windows and on gold and silver shillings during the reign of Sultan Muzaffar Shah (1455 - 1459). Calligraphy could also be found on medals, pottery, bronzes and silver". Based on the calligraphy used, it is obvious that Jawi script was used largely in the Malay society from the year 1300 .

"Other than calligraphy, I also use the hilt of the dagger and stylised it to portray the symbol of the Malay society... as a weapon". (25.9.12). The dagger's hilt acts as the holder and was normally shaped according to the grasp of hands. 'Keris' is a short form of dagger used largely by the Malays over 600 years ago. 'Keris' too is a symbol of heroism to the Malays, besides being used for safety, strength, pride and influence purposes. Nowadays, 'keris' is no longer used as weapon. However, it is still used by the 'bomoh' (Malay medicine-man) to cure pains, a symbol used by the Malaysian government, in honour of the king and country, and as part of the costume used for the traditional marriage ceremony of the Malays' bridegroom. The image of dagger's hilt used by the artist had indirectly encouraged the artist to appreciate the Malay heritage that is slowly being cast by modern societies.

The sculpture was coloured with colours of natures (greens) and with the forms of coiled handles derived from plants to symbolise the decencies of the Malays. "The blending of warm and cold colours had produced harmony... portrayed the colours of nature". (7.2.13).

\subsection{Personal Beliefs about Nature of Art}

Personally, the artist felt that mood plays an important role in producing an art piece. He trusted that this factor had influenced the other artists on working with their art pieces. Through his past experiences, he discovered that mood could influence the forming process. The artist normally would not work on his sculpture when he was facing personal problems. He believed that restless mind could affect his concentrations during the 'throwing' session. His mind should be free of any disturbance since the artist used the technique of multiple section form where each different form and parts were combined to form a complete sculpture. If the artist lose his concentration, the thrown form would not appear exactly as what he wanted and the joined part would be defected or lost its unity between one form and another. The throwing 
process often failed when the artist was in a moody state. Whenever this happened, the artist would stop work since he knew that it would affect the whole forming process. It would be a waste in terms of time and energy. "It was warm since firings were carried out and the workshop was fully occupied by students... the artist lost his interest to start throwing the forms". (25.9.12). The artist felt that he could feel the satisfaction if the forms to be produced turn out naturally.

According to Mulyadi Mahmood (1993, p. 49), "An artist is free to form any ceramics art but he needs to face scientific processes which require discipline and patient". Based on the statement, the artist believed that self-discipline is important in order to complete the artworks. "Working on with calligraphy (Jawi script)...Salam I - for four days". (21.2.12). Self-discipline is needed in the forming process that had been planned from the beginning of the sketches until the final stage, which is during the application of the calligraphy. In order to obtain a satisfying product, there should not be a short cut. For example, some sculptors are not bothered to carry out research and make sketches at the early stage. They prefer to make use of spontaneous ideas in building their sculptures. The artist felt that this could lessen the fluency of the process and affects the development of creative ideas.

Being creatively experienced and skilful in a certain technique are the keys for an artist to produce a good quality of artworks, as opinioned by the artist. "Almost seven years were spent to learn the throwing technique...". (21.10.12). This belief had somehow encouraged him to build a complicated and large form of sculptures by clay. With his creativity, the artist had finally thought of the ways to fire the three-dimensional sculpture without a stand and the tailed plate in the electric kiln. "Preparing a cylinder prop from clay...". (18.11.12). Three years ago, whenever the artist formed huge sculptures, he would face problems such as cracking on the footing. However, after experimenting and learning from his past experiences, in this project, fifteen of his sculptures had been fired safely. 'Formed rings as stands to the sculptures' base so that the water content in the sculpture, during the firing would be free and not isolated... avoid sculptures from cracking". (18.11.12). Skilful in a certain technique of sculpture making especially on clays could somehow bring confidence to the artist in forming a complicated sculpture.

\section{Conclusion}

Based on the analysis carried out, it is clear that the two main factors had influenced the process of the artwork. The first factor is the Practical consideration of artwork and the second is Imagery, Idea, Processes involved with the artwork. Both are relate $d$ to each other and influenced the artist's work of art. It is obvious that the surrounding environment with sufficient equipment is the main factor that can influence the artist during the production process. A comfortable space and condition can also bring to the peace of mind the artist. Sufficient equipment can encourage the artist to explore his ideas creatively and expressively.

The artist had been giving full concentration all throughout the forming process of his sculpture. In this process too, the artist had a sort of 'communication' with the sculptures he had formed. To this, subconscious ideas sometimes appeared and some alterations had taken place from the actual sketches of the sculptures. Ultimately, the artist felt that the freedom of using different methods in all artworks could bring satisfaction and enjoyment to him.

\section{References}

Cosentino, P. (1985). Creative Pottery. Ebury Press, London.

Duane and Preble, S. (1994). Art Form. Harper Collin Collage Publisher, New York.

Herberholz, D. and Herberholz, B. (1994). Artwork for Elementary Teachers: Developing Artistic and Perceptual Awareness. WCB Brown \& Benchmark Publishers, California.

Ismail, S. Z. (1985). Rhythm, Line and Colour. Fajar Bakti Sdn. Bhd, Petaling Jaya.

Nelson, G. C. (1984). Ceramics: A Potter's Handbook. Holt, Rienhart and Winston, Inc. New York.

Mahammod, M. (199)3. Approaches to Art and Design. Dewan Bahasa dan Pustaka, Kuala Lumpur.

Ocvirk, O. G., Stinson, R. E., Wigg, P. R., Bone, O. R. and Cayton, D. L. (1998). Art Fundamentals: Theory and Practice. McGraw Hill Companies, Inc. New York.

Parsons, M. J. (1987). How We Understand Art. Cambridge University Press, New York.

Ragans, R. (1995). Art Talk. Glencoe McGraw-Hill Companies, Inc, New York.

Rice, T. D. (1996). Islamic Art. Thames and Hudson Ltd, London.

Sanusi, K. (1992). An Islamic Identity in Contemporary Malaysian Art: Achievements and Challenges. National Art Gallery, Kuala Lumpur.

Wallschlaeger, C. and Snyder, C. B. (1992). Basic Visual Concepts and Principles for Artists, Architects, and Designer. Wm. C. Brown Publisher, New York. 
Appendix I: Personal Practical Artwork

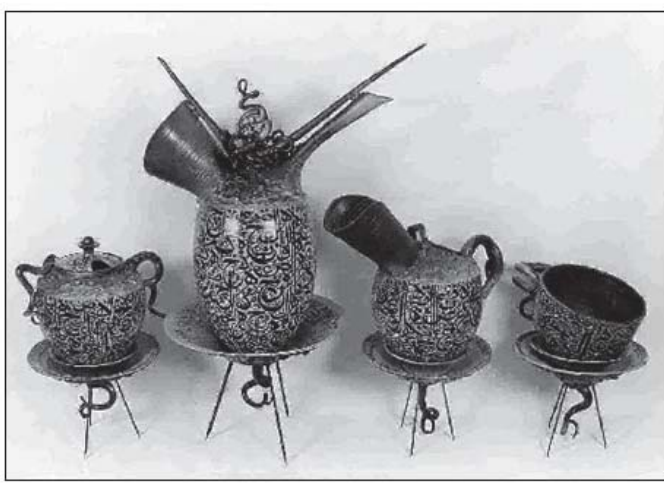

(A) Siri Tamu (Guest Series) XIII- Jemput (Welcome), 2012. Clay, $50 \mathrm{~cm} \times 30 \mathrm{~cm}, 32 \mathrm{~cm} \times 25 \mathrm{~cm}, 21 \mathrm{~cm} \times 28 \mathrm{~cm}, 21 \mathrm{~cm} \times 28 \mathrm{~cm}$
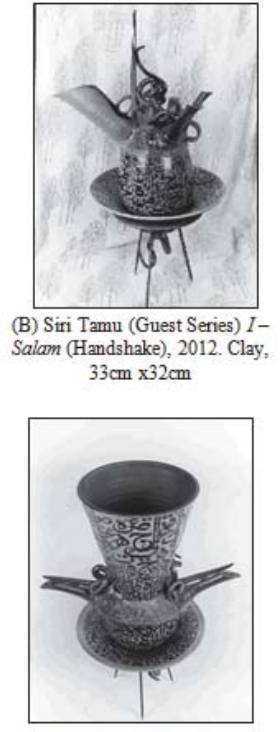

(D) Siri Tamu (Guest Series)
$X-$ Sapa (Great), 2012. Clay, $28 \mathrm{~cm} \times 17 \mathrm{~cm}$

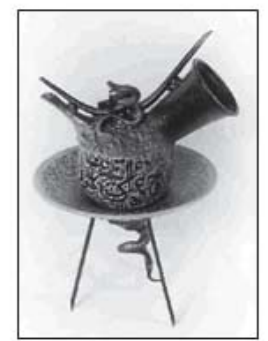

(F) Siri Tamu (Guest Series) VIIISila (Sit Cross - Legged), 2012. Clay, $38 \mathrm{~cm} \times 24 \mathrm{~cm}$
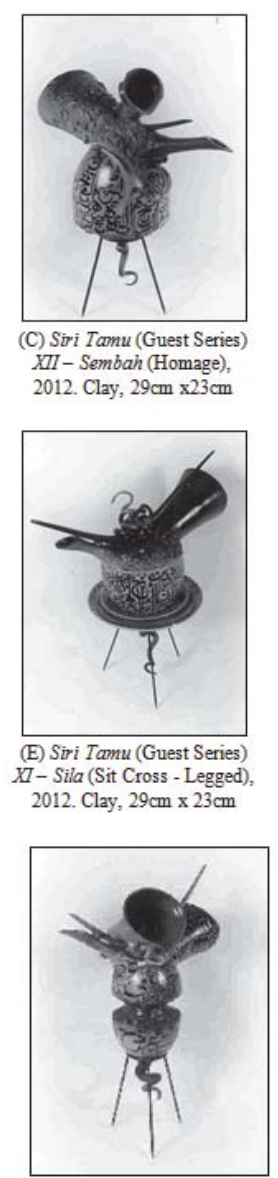

(G) Siri Tamu (Guest Series) VI-Sembah (Homage), 2012 Clay, $29 \mathrm{~cm} \times 19 \mathrm{~cm}$ 